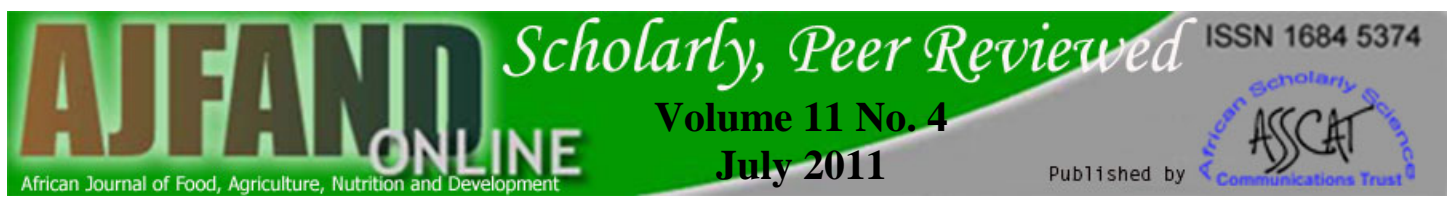

\title{
IMPACT OF THE NATIONAL SPECIAL PROGRAMME FOR FOOD SECURITY ON POVERTY ALLEVIATION AMONG WOMEN IN OYO STATE, NIGERIA
}

$$
\text { Ayoade } \mathrm{AR}^{1^{*}} \text {, Ogunwale } \mathrm{AB}^{1} \text { and JG Adewale }{ }^{1}
$$

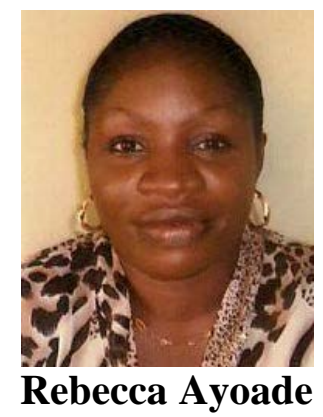

*Corresponding author email: ayonikea@yahoo.com

1 Department of Agricultural Economics and Extension, LadokeAkintola University of Technology, Ogbomoso, Nigeria. 


\section{ABSTRACT}

The study investigated the impact of National Special Programme for Food Security (NSPFS) on poverty alleviation among women in the three project sites of Oyo State, Nigeria. The study identified the socio-economic characteristics of women participants and non-participants and investigated the projects carried out under the programme. Also, the study examined the participants' and non-participants' present conditions of living, and finally compared farm size, output and income before and after the programme. Purposive sampling technique was used to select 166 participants from the sites of the programme while Systematic sampling technique was used to select 110 non- participants from the list of the farmers provided by the Agricultural Development Programme (ADP) officials in Oyo State. A structured interview schedule was used to gather information from the respondents. Data collected were collated and subjected to both descriptive and inferential statistics such as frequency counts, percentages and Tobit regression estimates. Results of data analysis revealed that most (39.8\%) of the women participants are middle-aged and still active in agricultural production. In addition, majority (60.2\%) of the participants were literate and participated more in cassava and maize production, while insufficient loan ranked first among the problems encountered by the participants. The estimates of Tobit regression analysis showed that a significant relationship existed between respondents' output $(-0.0000344, \mathrm{p}<0.01)$, participation level $(-0.0377$, $\mathrm{p}<0.01)$, marital status $(0.3722, \mathrm{p}<0.05)$ and poverty alleviation through the programme. However, the effects of marginal changes of Tobit regression analysis showed that poverty was significantly reduced by increased output (-0.13) and participation level (-2.49). This means the programme has impacted positively on the participants especially in the area of agricultural production. In view of these, the study recommends that sufficient input such as improved seeds, fertilizers, agrochemicals should be made available to the participants in the programme, based on the problems encountered by the participants. The programme should be expanded to cover more areas thus, increasing the number of sites and participants. This would also extend the benefits of the programme to more people. Also, participants should be encouraged to utilize their loans judiciously and possibly be given more training along with the loan to have maximum returns.

Key words: poverty, alleviation, impact, output, participation 


\section{INTRODUCTION}

Poverty in Nigeria has been a long standing issue and its reality is manifested in worsening incidence and severity over the years, despite the vast human and natural resources, economic and development potentials the country is blessed with. The issue of poverty is multi-dimensional and encompasses issues such as inadequate income, malnutrition, and poor social status especially in the rural areas [1].

The percentage of women below the poverty line has increased by $50 \%$ since the 1990s while the comparable figure for men increased only by 30\% [2].The author further explained that the income generated by women through farming, processing and marketing of products, is used to improve the well-being of their families and communities. However, their contributions are often limited by poor access to resources as a result of cultural, economic and sociological factors. The agricultural sector in Nigeria is dominated by female food producers, who live in poverty [3], and this is as a result of the abject conditions of the rural environment which have caused men to migrate into the urban areas leaving behind women and children to contend with the poor living condition in the areas.

The condition of women in Nigeria has been characterized by overwork, low productivity, limited access to credit, land, agricultural information, training and technology. It is evident that development in the rural areas is trapped in the vicious cycle of poverty. The escape from this is tied up in sustainable, feasible and implementable programmes with women as the focal point. A lot of development efforts have been concentrated in this direction to improve their condition of living through improved agricultural production, training and dissemination of information that facilitate effective utilization. Many rural development programmes have been implemented to improve women's conditions and better their lots. Field work has shown that most of these programmes did not get to the target audience while some have not been effective. This is due to the fact that the main participants in these programmes and projects are not involved in the design and could not meet their current needs, and due to lack of coordination among institutions which actively promote women's activities at local, regional, national and international levels [4]

As a result of this, National Special Programme for Food Security (NSPFS) was implemented to ensure food security and poverty alleviation among women and men. It is meant to assist farmers increase output and incomein order to strengthen extension delivery, promote simple farm technologies, and utilize land, water and other resources for food production through the loan disbursed per project. There is need to evaluate the impact of this programme so as to improve measures to redirect efforts and resources towards improving the quality of life of the people.

This study investigated the impact of National Special Programme for Food Security with women as the focal point because globally, the feminization of poverty is evident in the growing number of women with dependent children in the ranks of low paid workers, while poverty among women is growing faster than among men.

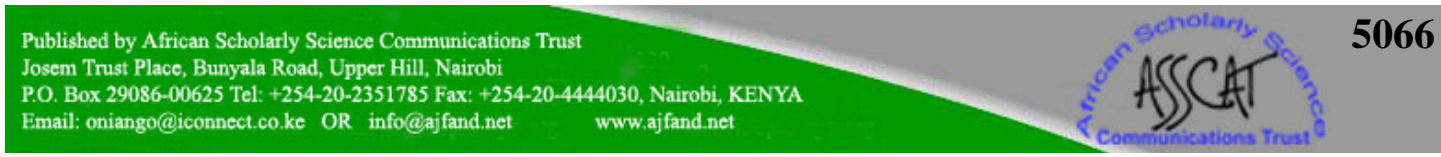




\section{Objectives of the Study}

The major objective of the study was to determine the impact of NSPFS in alleviating poverty among women in Oyo State, Nigeria. The specific objectives of the study were to:

i. examine socio-economic characteristics of the participants and nonparticipants in the project sites;

ii. examine different projects for which the women received financial assistance under the NSPFS to ensure food security and poverty alleviation?

iii. investigate the problems encountered by the participants in the programme

iv. compare the condition of living, farm size, outputs and incomes of the participants before and after their participation in the programme.

\section{Research Hypothesis}

Based on the objectives of the study, the following hypothesis was postulated.

$\mathrm{Ho}_{1}$ : There is no significant relationship between poverty alleviation level and selected characteristics of the participants.

\section{METHODOLOGY}

\section{The Study Area}

The study area is Oyo state of Nigeria. The state has a growing population of about 3,488,789 (NPC, 2005). Oyo state is dominated by Yorubas who are predominantly indigenes of the state, although there are federal government workers and private business workers who may or may not be indigenes.

The three NSPFS sites in Oyo state, namely: Ogbomoso, Akufo and Ilora were included in this study. It was discovered that the women participants of the programme were few. Therefore, all the female participants were included in the study. In Ogbomoso site, there were 13 groups of which women constitute about one third of the total participants in each group, with the number of women per group ranging between 8 and 13, making a total of one hundred and six participants. In Akufo site, there were two (2) separate women groups of 20 participants each making a total of 40 participants and Ilora site has only one women group with 20 participants. A total of one hundred and sixty six (166) women participants in the three sites constitute the sample of participants.

Non-participants were purposively sampled from the three NSPFS. Systematic sampling of the respondents was done by selecting every fourth name on the list of the women farmers provided by the ADP officials. Fifty non-participants were selected in Arowomole block (Ogbomoso site of NSPFS) while forty and twenty nonparticipants were respectively selected from Afijio block (Ilora site of NSPFS) and Ido block (Akufo site of NSPFS).This makes about fifty per cent in Arowomole block and equal number of participants in Afijio and Ido block because of the fewer number of participants. In all, there were one hundred and ten (110) non-participants for the study. 
Structured interview schedule was employed to gather data from the sampled women. Information was obtained on respondents' level of incomes, outputs and size of farmland before and after the programme and their socio-economic characteristics.

\section{Measurement of Variables}

The dependent variable of this study is poverty alleviation level among women participants. This was determined by impact on agricultural production and condition of living. The impact on agricultural production was measured by difference in size of farmland, income and output level before and after the programme, while impact on condition of living was measured by five items on a 3-point scale, which were high, moderate and low. The condition of living items include quality of housing, health status, personal mobility, access to safe drinking water and consumption of safe drinking water. The maximum obtainable impact score on condition of living was 15 and the minimum was 5 . This was obtained by the summation of the scores of the five items. The independent variables of this study are the factors which influence the participation of the women farmers in the programme. They include respondents' socio-economic factors such as farmers' age, religion, marital status, level of formal education and household size. Other selected variables are level of participation, farm size, income and output of women farmers before and after the programme.

Descriptive statistics such as frequency counts and percentages were used to describe the independent variables while Tobit regression analysis was used to determine types of relationships between the variables in the stated hypothesis.

\section{RESULTS}

\section{Age of respondents}

The age distribution depicts that participants are younger with mean age of 42.30years than the non-participants with mean age of 46.22years.Both groups are, however, in their active age to train and nurture their children coupled with other household responsibilities [5].

\section{The Marital Status}

Table 1 shows the marital status of the two groups. Majority of the participants (86.7\%) were married. The above findings show that large proportion of women in the programme were married and within their productive years. This finding agrees with a finding that reported that majority of rural women involved in agricultural production were married and were within their productive years [6].It is also supported by another finding that the wishes and interests of the women's husbands may have roles to play in their extent of participation [7].

\section{Contribution to resources}

Table 1 also reveals that most of the participants (63.9\%) had equal contribution with their husbands. About $7.2 \%$ were the major contributors and $28.9 \%$ were sole contributors to family resources. Also with the non-participants, $64.5 \%$ had joint 


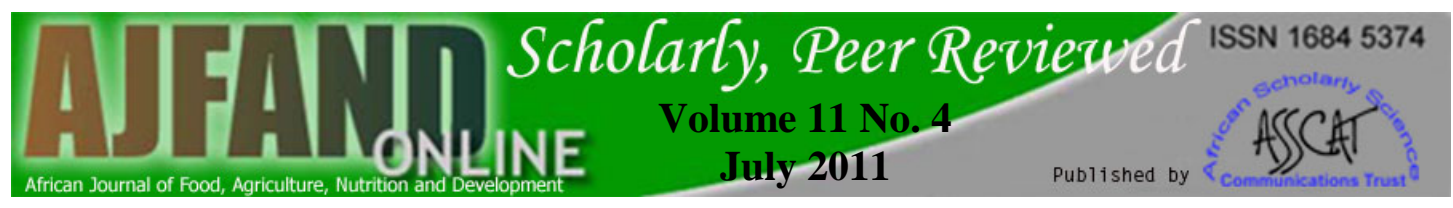

contribution with their husbands, $15.5 \%$ were the major contributors while $20 \%$ were sole contributors to family resources.

\section{Educational level}

This study reveals that the formal educational level of the participants of the programme was low as most of the respondents (39.8 per cent) had no formal education. This result is in line with the observation of the programme facilitators who remarked that poor formal educational level did not affect the women's participation in the programme because the programme facilitators led the women into basic literacy skills acquisition. About $40.0 \%$ of the participants acquired basic literacy skills from the facilitators.

\section{Household Size}

Table 1 further shows the household size of the two groups. Most of the participants (71.08\%) had between 1 and 5 people in each of their households and 28.91\% had between 6-10 people. While 25.51\% of the non-participants had between 1 and 5 people in each of their household, $69.10 \%$ had between 6 and 10 people in their household and $5.4 \%$ had between 11 and 15 people.

\section{Types of Project for which women received financial assistance}

Data in Table 2 show low participation in soyabeans production while participation levels in vegetable, poultry, animal production projects are fairly high. However, projects like cassava and maize farming recorded high participation. These results clearly indicate that the respondents were concerned about household food security and other domestic needs. The women received financial assistance in terms of loans which were to projects carried out.

\section{Comparison of living conditions of participants before and after the programme}

The results on table 3 shows that respondents in the three sites of the programme reside in houses built with zinc roof, brick and cemented walls before the programme started and no significant difference in housing condition was recorded after their involvement in the programme.

The table further reveals that most of the respondents (31.5\%) were used to selfmedication before the programme started. However, under the programme, the number of respondents receiving treatment in health centers increased to $65.7 \%$. This means the NSPFS has provided them with necessary enlightenment to improve their health status. Also, table 4 reveals the mobility status of the respondents. Most of the respondents $(97.6 \%)$ were in possession of neither motorcar nor motorcycle before their participation in the programme. After participating in the programme, the number reduced to $91.6 \%$ with $4.8 \%$ in possession of personal motorcars. This means the programme has increased their purchasing power as a result of increased productivity and disposable income. 
Farm Size, Output and Income Level of participants before and after their participation in the programme

Table4 serves as a proxy table for other tables under this objective. The table shows that all the respondents reported increase in their farm size, output and income. This implies that the participants' involvement in NSPFS has enabled them to expand their farm size as well as increase their output and income.

\section{Problems encountered by the participants}

Table 5 presents problems encountered by the participants. Insufficient loan ranked first among the problems encountered by the participants. Next to this was lack of input supply, followed by batch disbursement of fund, top-bottom approach of administration, late disbursement of fund and inadequate irrigation facilities, respectively.

Two thirds of the mean income of both participants and non- participants was calculated to determine the poverty line. This was used in classifying the respondents into poor and non -poor group. From this classification, most of the participants (71.72\%) fell into non-poor category before the programme and the remaining $28.3 \%$ fell into the poor category, after which there was an 11.4 per cent increase in the nonpoor category after their participation in the programme.

\section{Hypothesis Testing}

$\mathrm{Ho}_{1}$ : There is no significant relationship between poverty alleviation level and selected characteristics of the women participants.

\section{Tobit Regression Analysis}

Tobit regression analysis was used to determine and quantify the relationship between poverty levels and selected variables.

$$
\begin{aligned}
\mathrm{Y}_{\mathrm{i}} & =\mathrm{P}_{1}=\mathrm{X}_{\mathrm{i}} \beta+\mathrm{e}_{\mathrm{i}} \text { if } \mathrm{P} 1 \geq \mathrm{P} 1 * \\
& =0=\mathrm{X}_{\mathrm{i}} \beta+\mathrm{e}_{\mathrm{i}} \text { if } \mathrm{P} 1 \leq \mathrm{P} 1 * \\
\mathrm{I} & =1,2, \ldots \ldots \ldots \mathrm{n}
\end{aligned}
$$

Where,

$$
\begin{aligned}
& \mathrm{Y}_{\mathrm{i}}=\text { the dependent variable } \\
& \mathrm{P}_{1}=\text { poverty intensity defined as: } \frac{\left(\mathrm{Z}-\mathrm{y}_{\mathrm{i}}\right)}{\mathrm{Z}}
\end{aligned}
$$

and $\mathrm{Z}=$ poverty line

$\mathrm{y}_{\mathrm{i}}=$ mean income

$\mathrm{P}_{\mathrm{j}}{ }^{*}=$ poverty intensity when poverty line equals income

$\mathrm{X}_{\mathrm{i}}=$ explanatory variables

$\beta=$ vector of explanatory variables

$\mathrm{e}_{\mathrm{i}}=$ independent distributed error term. 


\section{Poverty line $=2 / 3$ of mean income}

The result of the relationship between poverty alleviation and selected characteristics was achieved using Tobit model as specified in the methodology.

The result shows that the sigma $(\delta)$ value is 0.3063 with a t-value of 6.992 , which is statistically significant at $1 \%(\mathrm{P}<0.01)$. This indicates that the model has a good fit to the data in the analysis. Three of the eight variables, estimated in the model were statistically significant at different levels between one percent $(\mathrm{P}<0.01)$ and five percent $(\mathrm{P}<0.05)$ levels of significance.

\section{Tobit estimates of the impact of NSPFS on poverty among the participants}

\section{Output}

The coefficient with respect to output(in $\mathrm{Kg}$ ) is -0.0000344 and is statistically significant $(\mathrm{P}<0.01)$. This result implies that output is a significant factor in poverty alleviation among women in the study area. The negative sign on the coefficient implies that a unit increase in the output of the women will lead to $34.4 \%$ reduction in poverty, which is a substantial reduction.

Level of participation The coefficient with respect to level of participation is -0.0377 and is statistically significant at $1 \%(\mathrm{P}<0.01)$. This shows that participation has a significant effect on poverty alleviation among the women. However, the negative sign conforms to a priori expectation. This explains that poverty among the women is alleviated with their participation in the programme.

Marital Status The coefficient of intercept dummy of marital status of the women is 0.3722 and is statistically significant at $5 \%$ level of significance. However, this result shows that the poverty level of married women will be increased by 0.372 to become 1.6222 while that of others will remain at 1.250.

Tobit estimates of probability and effects of marginal changes in the explanatory variables on poverty status of the participants

\section{Output}

The coefficient of elasticity of probability of poverty is -0.00161 , hence it is inelastic. This shows that $100 \%$ increase in output will lead to $16 \%$ reduction in the probability of being poor. On the other hand, the coefficient of elasticity of the intensity of poverty to an increase in output is -0.13 .This means that the intensity of poverty will reduce by 13 percent for 100 percent increase in output hence it is inelastic. The analysis shows that an increase in output decreases the intensity of poverty than its probability.

\section{Participation Level $\left(\mathbf{X}_{2}\right)$}

The coefficient of elasticity of probability of poverty is -0.00311 , hence it is inelastic. This shows that 100 percent increase in participation will lead to 0.311 percent reduction in the probability of being poor. On the other hand, the coefficient of elasticity of the intensity of poverty to an increase in participation level is -2.49 


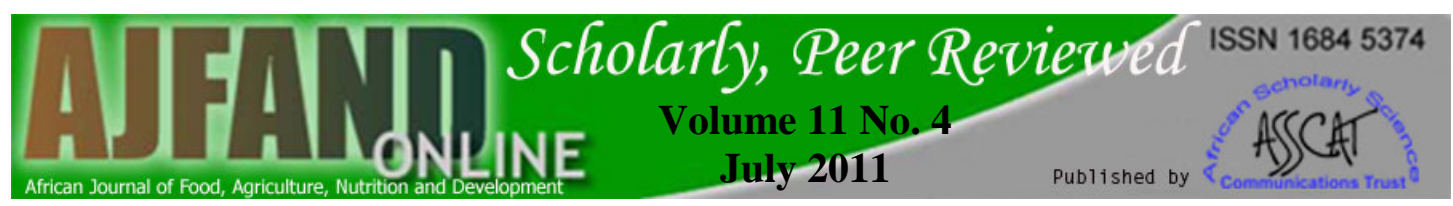

percent. This means that the intensity of poverty will reduce by 24.9 percent for 100 percent increase in level of participation. This shows that an increase in level of participation decreases the intensity of poverty more than its probability.

\section{Marital Status $\left(\mathrm{X}_{4}\right)$}

The coefficient of elasticity of the probability of poverty alleviation is 0.00143 , hence it is elastic. This shows that 100 percent increase in married status of the women will lead to 0.143 percent increase in the probability of the women being poor. On the other hand, the coefficient of elasticity of the intensity of poverty to an increase in married status is 0.11 .

\section{DISCUSSION}

The age distribution reveals that majority of the women were energetic, young and agile to actively participate in the programme activities. Hence, they will be expected to benefit immensely from the programme and improve their productivity to reduce poverty level in the rural communities. The contribution of women to family resources and their participation in NSPFS implies that there is the need to provide for their children or support their husbands in providing for their families [8].This study reveals that the educational level of the participants of the programme was low. This result is in line with the observation of the programme facilitators who remarked that poor formal educational level did not affect the women's participation in the programme, as the programme facilitators led the women into basic literacy skills acquisition. Most of the non-participants had larger household size while the participant had smaller households. It is expected that the smaller the household size, the better the condition of living and health status and also the higher the frequency of protein intake. This finding also suggests the need to increase birth spacing at household level in order to improve standard of living and increase frequency of intake of protein to improve family health care. High participation in cassava and maize production may reflect the crops as major staple food for home consumption and income generation, apart from guaranteeing their household food security [9].

There was an increase in consumption of borehole water from $12.1 \%$ before and $19.9 \%$ after the programme. Other benefits such as improved health care system, mobility status and access to portable water have improved the socio-economic status and self-worth of the participants in their communities. This finding agrees with a World Bank study, which reported that the essence of community participation in rural development programme is the improvement in socio-economic characteristics and self-worth after participation in such programmes [10]. Increase in income is likely to reduce poverty level and improve the participants' condition of living. Then participants by this will be better off than before and be able to enjoy better conditions of living in their communities [11]. There is an increase of $11.4 \%$ of the total respondents from poor to non-poor category after the programme, which confirms the positive impact of NSPFS programme on poverty condition of the respondents. 


\section{CONCLUSION}

Poverty reduction and food security in Oyo State have proved to be of immense challenge not only to the state but the nation as a whole. The study focused on women because of the significant role they play in the overall welfare of their families. The study makes the following conclusions on the basis of the findings of the study. Most (78.4\%) of the project participants were within their active age. Hence, they will be expected to participate actively in their project activities. Majority (86.7\%) of the participants were married, literate with an average household size of 4 members. Most (63.9\%) of the participants joined their husbands in contributing to the family welfare in cash and kind. Most of the women involved in the projects were cultivating cassava and maize as the major stable food for home consumption and income generation. Also, the women's participation has significantly improved their mobility status and borehole water consumption. Loans provided for the project participants assisted the recipients in boosting their farm productivity as a result of increased in farm size cultivated. A significant relationship was found between output, level of participation, marital status and poverty alleviation level.

In view of these, the study recommends that sufficient input such as improved seeds, fertilizers, agro-chemicals should be made available to the participants in the programme, based on the problems encountered by the participants. The programme should be expanded to cover more areas, thus increasing the number of sites and participants. This would also extend the benefits of the programme to more people. Also, participants should be encouraged to utilize their loans judiciously and possibly be given more training along with the loan to have maximum returns. 


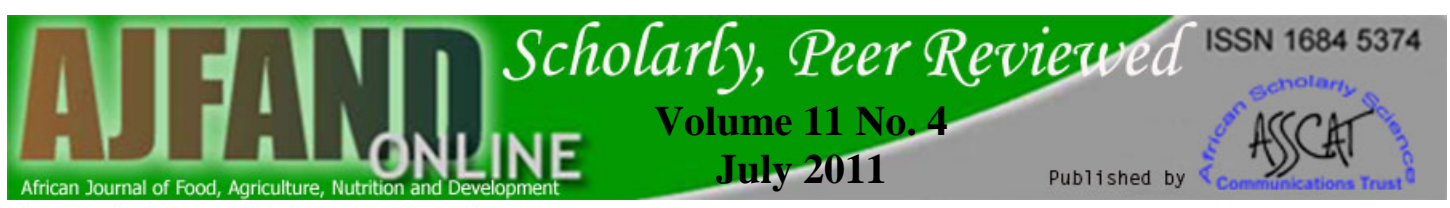

Table 1: Distribution of respondents by their socio-economic characteristics

\begin{tabular}{lllcl} 
Variables & \multicolumn{2}{c}{ Participants } & \multicolumn{2}{c}{ Non-Participants } \\
Age(yrs). & Frequency & $(\%)$ & Frequency & $(\%)$ \\
\hline $20-29$ & 16 & 9.7 & 2 & 1.8 \\
$30-39$ & 48 & 28.9 & 11 & 10.0 \\
$40-49$ & 66 & 39.8 & 59 & 53.6 \\
$50-59$ & 29 & 17.5 & 26 & 23.6 \\
$60-69$ & 5 & 3.0 & 12 & 10.9 \\
$70-79$ & 2 & 1.2 & 0 & 0.0 \\
Total & 166 & 100 & 110 & 100
\end{tabular}

Marital Status

\begin{tabular}{lllll}
\cline { 1 - 1 } Married & 144 & 86.7 & 3 & 88.2 \\
Single & 6 & 3.6 & 97 & 2.7 \\
Separated & 2 & 1.2 & 10 & 9.1 \\
Divorced & 2 & 1.2 & 0 & 0.0 \\
Widowed & 12 & 7.2 & 0 & 0.0 \\
Total & 166 & 100 & 110 & 100
\end{tabular}

$\underline{\text { Religion }}$

Christianity

Islam

61

36.7

63.3

Traditional

105

0.0

3

2.7

Total

166

100

89

80.9

16.4

$110 \quad 100$

Contribution

Sole Contributor $\quad 48$

28.9

7.2

20.0

Major Contributor $\quad 12$

63.9

15.5

Joint with husband $\quad 106$

100

64.5

Total

166

71

100

Education level

Tertiary education 1

6.0

2.7

Completed Sec. edu. $\quad 25$

15.1

10.9

3.0

10.9

Incomplete Sec. ed 5

26.5

29.1

Incomplete pry educ. 10

6.0

10.0

Christian Theological 1

6.0

4.5

4.8

4.5

Islamic school

3.6

9.1

Adult education 6

39.8

18.21

No- formal education 66

100

100

Household size (members)

$\begin{array}{ll}1-5 & 118 \\ 6-10 & 48 \\ 11-15 & 0 \\ \text { Total } & 166\end{array}$

71.0

25.5

28.0

69.1

Total

166

0.0

100

5.4

100

Source: Field Survey, 2006 


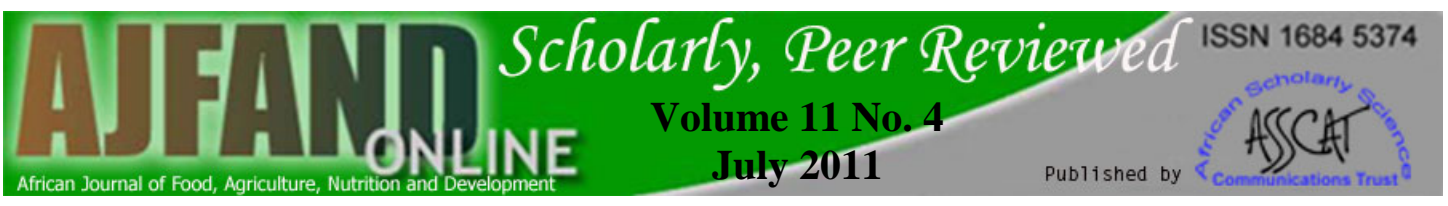

Table 2: Distribution of respondents by projects for which women received financial assistance

\begin{tabular}{lcc} 
Projects & Frequency & Percentages \\
\hline Animal Husbandry & 11 & 6.6 \\
Cassava & 79 & 47.6 \\
Maize & 53 & 32.0 \\
Poultry & 8 & 4.8 \\
Soya & 6 & 3.6 \\
Vegetable & 9 & 5.4 \\
Total & $\mathbf{1 6 6}$ & $\mathbf{1 0 0}$ \\
\hline
\end{tabular}

Source: Field survey, 2006 
Table 3: Distribution of participants by living condition before and after their participation in the programme

Condition

\begin{tabular}{lrrr}
\multicolumn{2}{c}{ Before } & \multicolumn{2}{c}{ After } \\
F & $\%$ & F & $\%$
\end{tabular}

\section{Housing}

Thatched roof with mud walls

0

0.0

0.0

Thatched roof with cemented wall

0

0.0

0.0

Zinc roof with brick and cemented walls

166

100

$166 \quad 100$

\section{Health care}

Self medication

52

31.3

2

1.2

Spiritual / orthodox

36

21.3

55

Hospital/health centre

78

47.0

109

65.7

\section{Mobility}

None

162

97.6

152

91.6

Motorcycle/ bicycle

$\begin{array}{ll}0 & 0.0\end{array}$

8

4.8

Motorcar

4

2.4

6

3.6

Access to water

Spring

32.5

49

29.5

Well

Borehole

\section{Consumption of water}

\begin{tabular}{lcccc} 
Spring & 54 & 32.5 & 49 & 29.5 \\
Well & 92 & 55.4 & 84 & 50.6 \\
Borehole & 20 & 12.1 & 33 & 19.9 \\
\hline Total & $\mathbf{1 6 6}$ & $\mathbf{1 0 0}$ & $\mathbf{1 1 0}$ & $\mathbf{1 0 0}$ \\
\hline
\end{tabular}

Source: Field Survey 2006 
Table 4: Distribution of Maize growers by their Farm Size, Output and Income Level before and after their participation in the Programme

\begin{tabular}{|c|c|c|c|c|}
\hline \multicolumn{5}{|c|}{$\mathbf{N}=53$} \\
\hline \multirow[t]{2}{*}{ Parameter } & \multicolumn{2}{|c|}{ Before } & \multicolumn{2}{|c|}{ After } \\
\hline & $\mathbf{F}$ & $\%$ & $\mathbf{F}$ & $\%$ \\
\hline \multicolumn{5}{|l|}{ Farm Size (Ha) } \\
\hline$<0.10$ & 39 & 73.6 & 0 & 0.0 \\
\hline $0.10-0.49$ & 4 & 7.6 & 0 & 0.0 \\
\hline $0.50-0.99$ & 6 & 11.3 & 0 & 0.0 \\
\hline $1.00-1.49$ & 4 & 7.6 & 30 & 56.6 \\
\hline $1.50-1.99$ & 0 & 0.0 & 5 & 9.4 \\
\hline 2.00 and above & 0 & 0.0 & 18 & 34.0 \\
\hline \multicolumn{5}{|l|}{ Output (Kg) } \\
\hline $100-499$ & 43 & 81.1 & 4 & 7.6 \\
\hline $500-999$ & 9 & 16.9 & 12 & 22.6 \\
\hline $1000-1499$ & 1 & 11.9 & 15 & 28.3 \\
\hline 1500-1999 & 0 & 0.0 & 16 & 30.2 \\
\hline $2000-2499$ & 0 & 0.0 & 5 & 9.4 \\
\hline 2500-2999 & 0 & 0.0 & 0 & 0.0 \\
\hline 3000- and above & 0 & 0.0 & 1 & 1.9 \\
\hline \multicolumn{5}{|l|}{ Income Level (\#) } \\
\hline$<5000$ & 5 & 9.4 & 0 & 0.0 \\
\hline 5000-9999 & 6 & 11.3 & 0 & 0.0 \\
\hline 10,000-14, 999 & 20 & 37.7 & 2 & 3.8 \\
\hline 15,000-19, 999 & 13 & 24.5 & 0 & 0.0 \\
\hline $20,000-24,999$ & 2 & 3.8 & 5 & 9.4 \\
\hline 25,000-29, 999 & 2 & 3.8 & 6 & 11.3 \\
\hline 30,000-34, 999 & 3 & 5.7 & 0 & 0.0 \\
\hline 35,000-39, 999 & 0 & 0.0 & 0 & 0.0 \\
\hline $40,000-44,999$ & 2 & 3.8 & 13 & 24.5 \\
\hline $45,000-49,999$ & 0 & 0.0 & 3 & 5.7 \\
\hline 50,000 and above & 0 & 0.0 & 24 & 45.3 \\
\hline
\end{tabular}

Source: Field Survey, 2006 


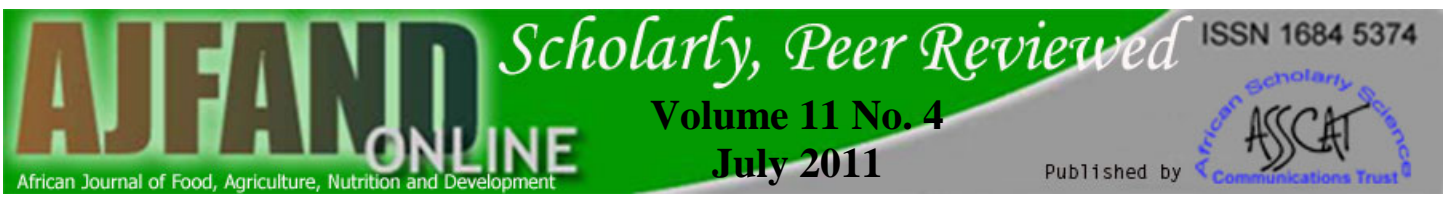

Table 5: Distribution of respondents by problems encountered

\begin{tabular}{lllc}
\hline Problems & Frequency* & \% & Rank \\
\hline Insufficient loan & 166 & 100 & 1 \\
Lack of input supply & 108 & 65.1 & 2 \\
Batch disbursement of fund & 88 & 53 & 3 \\
Top-bottom approach of Adm. & 65 & 39.2 & 4 \\
Late disbursement of funds & 60 & 36.1 & 5 \\
Inadequate irrigation facilities & 10 & 6.0 & 6 \\
* Multiple responses & & & \\
Source: Field Survey, 2006 & &
\end{tabular}


Table 6: Distribution of respondents by poverty line before and after the programme

Poverty line before the programme

\begin{tabular}{lcccc} 
& \multicolumn{2}{c}{ Participants } & \multicolumn{2}{c}{ Non-Participants } \\
& Frequency & $\%$ & Frequency & $\%$ \\
Poor & 47 & 28.3 & 68 & 61.8 \\
Non-poor & 119 & 71.7 & 42 & 38.2 \\
Total & 166 & 100 & 110 & 100
\end{tabular}

Poverty line after the programme

\begin{tabular}{lcccc} 
& \multicolumn{2}{c}{ Participants } & \multicolumn{2}{c}{ Non-Participants } \\
& Frequency & $\%$ & Frequency & $\%$ \\
Poor & 28 & 16.9 & 74 & 67.3 \\
Non-poor & 138 & 83.1 & 36 & 32.7 \\
Total & 166 & 100 & 110 & 100
\end{tabular}

Source: Field survey, 2006 


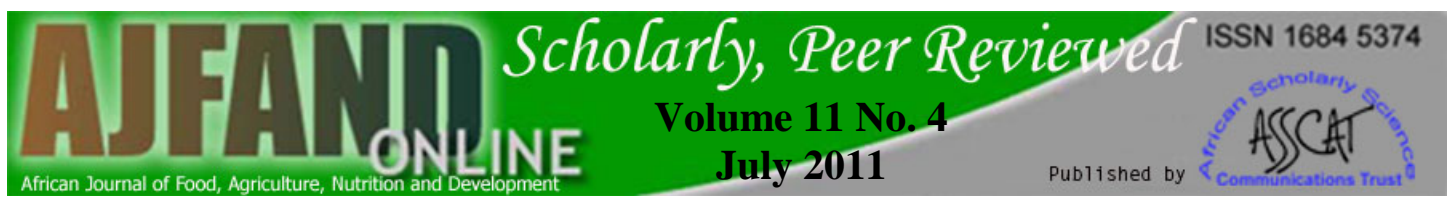

Table7: Tobit estimates of the impact of NSPFS on poverty level among women participants in Oyo State

\begin{tabular}{|c|c|c|c|c|c|}
\hline Variable & Coefficient & $\begin{array}{l}\text { Standard } \\
\text { Error }\end{array}$ & $\begin{array}{l}\text { b/St. } \\
\text { Er. }\end{array}$ & $\mathrm{P}[/ \mathrm{Z} />]$ & Mean of X \\
\hline \multicolumn{6}{|c|}{ Primary Index Equation for Model } \\
\hline Constant & 1.250511632 & .55173655 & 2.267 & .0234 & \\
\hline OUTPUT D & $-.3446866249 \mathrm{E}-04$ & .20134975E-04 & -1.712 & $.0869 *$ & 3746.7289 \\
\hline PARTISCO & $-3773423423 \mathrm{E} 01$ & $.53533990 \mathrm{E}-02$ & -7.049 & $.0000 *$ & 66.054217 \\
\hline AGE & $-.7319405420 \mathrm{E}-02$ & .94187639E-02 & -.777 & .4371 & 46.361446 \\
\hline MAR_STA & .3722518704 & .15966527 & 2.331 & $.0197 * *$ & .30722892 \\
\hline HOUSE SI & $.4883011148-01$ & .29706459E-01 & 1.644 & .1002 & 6.1265060 \\
\hline CONTRIBT & .1392721041 & .11223587 & 1.241 & .2146 & .36144578 \\
\hline YEAR_SPE & $-.5843232380 \mathrm{E}-02$ & $.16029286 \mathrm{E}-01$ & -.365 & .7155 & 3.8313253 \\
\hline FARMSIZ & $.7791723852 \mathrm{E}-02$ & $.73350754 \mathrm{E}-02$ & 1.062 & .2881 & 3.1493976 \\
\hline \multicolumn{6}{|c|}{ Disturbance standard deviation } \\
\hline Sigma & 3063548841 & $.43814833-01$ & 6.992 & .0000 & \\
\hline
\end{tabular}

Source: Computed from field survey, 2006.

**Sig.at $5 \%$

*Sig at $1 \%$ 


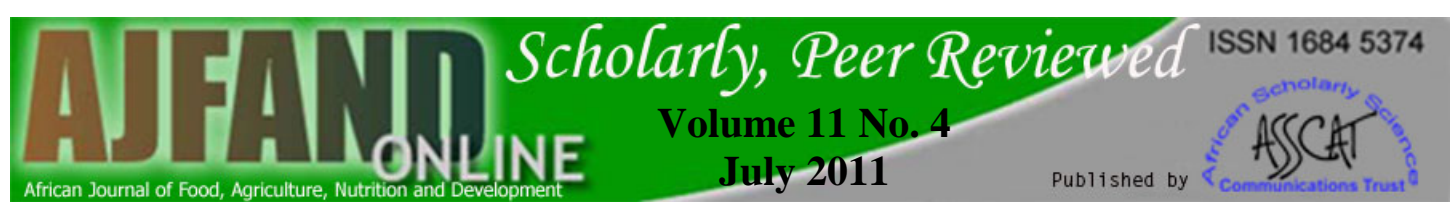

Table8: Tobit estimates of probability and effects of marginal changes in the explanatory variables on poverty status of the women

\begin{tabular}{|l|c|c|c|}
\hline \multicolumn{1}{|c|}{ Variables } & $\begin{array}{c}\text { Elasticity of } \\
\text { Probability }\end{array}$ & $\begin{array}{c}\text { Elasticity of } \\
\text { Intensity }\end{array}$ & Total Elasticity \\
\hline Output & $-0.00161^{*}$ & $-0.13^{*}$ & $-0.130161^{*}$ \\
\hline Part score & $-0.00311^{*}$ & $-2.49^{*}$ & $-2.49311^{*}$ \\
\hline Age & -0.0000423 & -0.34 & -0.3400423 \\
\hline Marital status & $0.00143^{* *}$ & $0.11^{*}$ & $0.11143^{*}$ \\
\hline Household size & 0.000373 & 0.30 & 0.300373 \\
\hline Contribution to household size & 0.000063 & 0.05 & 0.050063 \\
\hline Years spent & -0.000028 & -0.02 & -0.020028 \\
\hline Farm size & 0.0000307 & 0.02 & 0.0200307 \\
\hline
\end{tabular}

$* *$ Sig. at $5 \%$

$*$ Sig. at $1 \%$

Source : Field survey, 2006 


\section{REFERENCES}

1. Olowe K Gender Dimensions on Poverty Alleviation in Nigeria. Workshop on Gender and Sustainable Development. August 26-30 NCEMA Ibadan.2002:p2.

2. World Bank. Gender Dimensions on Poverty Alleviation in Nigeria. Workshop on Gender and Sustainable Development.NCEMA. Ibadan. August 26-30, 2002:3-4.

3. Adewale JG and TO Oladeebo Access of women farmers to land in Ogbomoso zone in Fabiyi Y.L and Idowu E.O. Editors, Poverty Alleviation and Food Security in Nigeria. A publication of Nigerian Association of Agricultural Economists (NAAE).1999:102- 109.

4. Olawoye $\mathbf{J}$ Gender Imbalance in the Development Process. Workshop on Gender and Sustainable Development NCEMA, Ibadan.2002:2-3.

5. Adekoya A, Onifade FA and OI Oladele Awareness and Participation in Family Support Programme Activities in Oyo State. Proceedings of $10^{\text {th }}$ Annual Conference of the Nigerian Rural Sociological Association, Obafemi Awolowo University, Ile-Ife. 2000:122-127.

6. Ekong E E Rural Sociology. An Introduction and Analysis of Rural Nigeria.Dove Educational Publishers, Uyo, Akwa Ibom State,Nigeria.2003: 343.

7.Ogunwale AB Influence of Socio-economic characteristics on women participation in selected Local Government Area of Oyo State (Ed) Community participation in rural development. Proceedings of the $10^{\text {th }}$ Annual Conference of the Nigerian Rural Sociological Association, Obafemi Awolowo University, Ile Ife. 2000:41-47.

8. Ironkwe AG and E Ekwe Rural Women's Participation in Agricultural Production in Abia State. Presented at $3^{\text {rd }}$ Annual Conference of the Agricultural Society in Nigeria at NCRI Baddegi, Bida .2000: $18^{\text {th }}-22^{\text {nd }}$ Oct.1999. Cited In: Ibrahim F.D and Olaleye F.S (2004): Poverty Alleviation Initiatives in Improving the Life of the Rural Women. A paper presented at $11^{\text {th }}$ NRSA Conference in LAUTECH.

9. Tanko NM Contribution of Rural Women to Agricultural Planning and Development in Nigeria.In: SustainableAgricultural Development in Nigeria.Winnockinternational2003:110 - 116.

10. World Bank. Participation Evaluation: Tools for managing rural development programme sanitation.World Bank Technical Paper. No.207.World Bank Washington D.C.1993:122.

11. Khandker R, Mestelm S and D Freery Farm size, Tenancy and Technology in Bangladesh, Canadian Journal of Development Studies.1986:(7) 2. 